Grant/research support from: MSD, R. Roque Grant/research support from: MSD, J. Rovisco Grant/research support from: MSD, M. Marques Grant/research support from: MSD, J. Tavares-Costa Grant/research support from: MSD, J. Silva Grant/research support from: MSD, H. Santos Grant/research support from: MSD, N. Madeira Grant/research support from: MSD, E. Vieira-Sousa Grant/research support from: MSD, R. Machado Grant/research support from: MSD, M. Bernardes Grant/research support from: MSD, R. Ferreira Grant/research support from: MSD, S. Ramiro Grant/research support from: MSD

DOI: 10.1136/annrheumdis-2018-eular.2558

\section{SAT0261 CERTOLIZUMAB PEGOL SERUM LEVELS $\geq 20$ MG/L ARE ASSOCIATED WITH TREATMENT RESPONSE IN PATIENTS WITH AXIAL SPONDYLOARTHRITIS. DATA FROM THE NOR-DMARD STUDY}

J.E. Gehin ${ }^{1,1}$, S.W. Syversen ${ }^{2}$, D.J. Warren ${ }^{1}$, G.L. Goll ${ }^{2}$, J. Sexton ${ }^{2}$, E.K. Strand ${ }^{3}$, T.K. Kvien ${ }^{2}$, N. Bolstad' ${ }^{1}$, E. Lie' ${ }^{2}{ }^{1}$ Department of Medical Biochemistry, Oslo University Hospital; ${ }^{2}$ Department of Rheumatology, Diakonhjemmet Hospital, Oslo; ${ }^{3}$ Lillehammer Hospital for Rheumatic Diseases, Lillehammer, Norway

Background: Measurement of serum drug levels can help clinicians tailor treatment with TNF-inhibitors. An association between certolizumab pegol (CP) serum levels and response has previously been found in patients (pts) with rheumatoid arthritis. ${ }^{1}$ Data for pts with axial spondyloarthritis (axSpA) are lacking.

Objectives: To examine the association between serum CP levels and treatment response in pts with axSpA and to identify a therapeutic target level.

Methods: Patients with a clinical diagnosis of axSpA starting standard treatment with CP included in the NOR-DMARD study with biobank sample at 3 months follow-up, were included in the present analyses. Serum drug levels (non-trough) were analysed with an in-house immunofluorometric assay automated on the AutoDELFIA immunoassay platform. Associations between CP level and improvement in ASDAS-CRP and response (defined as ASDAS clinically important improvement $(\mathrm{CII})$ ) were assessed by multivariable linear and logistic regression (adjusting for age, sex and prior bDMARD $(\mathrm{Y} / \mathrm{N})$ ), respectively.

Results: Median serum drug level at 3 month follow up was $35.0 \mathrm{mg} / \mathrm{L}$ (IQR $21.3-45.3$ in 116 pts. Response data were available in 110/116 patients. Serum $\mathrm{CP}$ level $\geq 20 \mathrm{mg} / \mathrm{L}$ was associated with improvement in ASDAS at 3 months $(\beta=0.55,(95 \% \mathrm{Cl} 0.12-1.98), p=0.01)$. Serum CP level $\geq 20 \mathrm{mg} / \mathrm{L}$ was associated with ASDAS Cll at 3 months (OR $3.4(95 \% \mathrm{Cl} 1.0-11.1, \mathrm{p}=0.045))$. Only $18.2 \%$ of pts with CP level $<20 \mathrm{mg} / \mathrm{L}$ achieved ASDAS CIl at 3 months, while $53.2 \%$ of pts with CP level $20-40 \mathrm{mg} / \mathrm{L}$ and $36.6 \%$ with $>40 \mathrm{mg} / \mathrm{L}$ were responders.
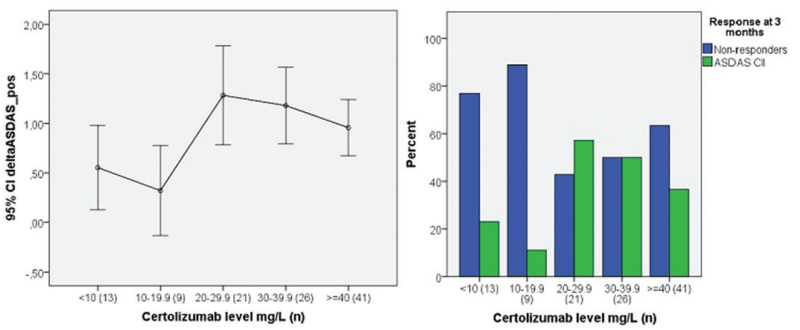

Conclusions: Serum CP level was associated with clinical response after 3 months of treatment in pts with axSpA. We suggest $20 \mathrm{mg} / \mathrm{L}$ as a lower target level for non-trough samples. No additional benefit of having a certolizumab level over $40 \mathrm{mg} / \mathrm{L}$ was observed. These results suggest that a therapeutic level of 20$40 \mathrm{mg} / \mathrm{L}$ can be implemented in clinical practice for non-trough serum samples in pts with axSpA.

\section{REFERENCE:}

[1] Jani M, et al. Ann Rheum Dis 2017;76(1):208-13.

Disclosure of Interest: J. E. Gehin Consultant for: Roche, S. Syversen Consultant for: Roche, D. Warren: None declared, G. Goll Consultant for: Abbvie, Biogen, Boehringer Ingelheim, Orion Pharma, Eli Lilly, Novartis, Pfizer, MSD, Roche, UCB, J. Sexton: None declared, E. Strand Consultant for: Pfizer, T. Kvien Consultant for: AbbVie, Biogen, BMS, Boehringer Ingelheim, Celgene, Celltrion, Eli Lilly, Epirus, Hospira, Merck-Serono, MSD, Mundipharma, Novartis, Oktal, Orion Pharma, Hospira/Pfizer, Roche, Sandoz, UCB, N. Bolstad Consultant for: Pfizer, Orion Pharma, Napp pharmaceuticals, Takeda, Roche, E. Lie: None declared DOI: 10.1136/annrheumdis-2018-eular.5252

\section{SAT0262 3-YEAR FOLLOW-UP OF A DOSE TAPERING PROTOCOL OF ANTI-TNF THERAPY IN A COHORT OF PATIENTS WITH SPONDYLOARTHRITIS (SPA) IN CLINICAL REMISSION UNDER CONDITIONS OF CLINICAL PRACTICE}

M.D.C. Castro Villegas ${ }^{1}$, E.-L. Saldarriaga ${ }^{2}$, P. Font Ugalde ${ }^{3}$, M. Romero Gómez ${ }^{1}$, J. Calvo Gutierrez ${ }^{1}$, R. Ortega Castro', E.C. López-Medina', R.A. Altamirano ${ }^{4}$, A. Escudero-Contreras ${ }^{3}$, E. Collantes Estévez ${ }^{3} .{ }^{1}$ Department of Rheumatology, Hospital Reina Sofía. IMIBIC., Cordoba, Spain; ${ }^{2}$ Department of Rheumatology, Universidad de La Sabana, bogota, Colombia; ${ }^{3}$ Department of Rheumatology, Hospital Reina Sofía. IMIBIC.Medicine Faculty Cordoba University; ${ }^{4}$ Department of Rheumatology, Medicine Faculty Cordoba University, Cordoba, Spain

Background: The dose tapering of biological therapy in patients in clinical remission is a strategy used in recent years in Rheumatology, consists in the reduction of the dose administered or in the extension of the interval between two doses, some studies suggest the possibility that patients with sustained remission could obtain the same benefit with a lower dose.

Objectives: Evaluate the effectiveness of 3 year follow-up of a dose tapering in patients with $\mathrm{SpA}$ in maintained clinical remission and detect possible predictors of maintenance of the response.

Methods: Retrospective observational study, all patients with SpA were included according to ASAS criteria, treated with antiTNF, with dose tapering, from October 2014-December 2017. Clinical remission defined by BASDAI $\leq 2$ and/or $\mathrm{CRP} \leq 5 \mathrm{mg} / \mathrm{L}$ for at least 6 months, establishing dose tapering as lower doses or longer intervals(according to the guidelines of the Spanish Society of Rheumatology and Pharmacy). Those patients who relapsed (BASDAI >2 and/or $\mathrm{CRP}>5 \mathrm{mg} / \mathrm{L}$ ) at any time during the study returned to the standard dose. Clinical and analytical parameters were collected (baseline and at the time of optimisation), as well as the survival of the drug and the efficacy parameters until the time of relapse and who continued in dose tapering.

Results: 149 patients with SpA in treatment with antiTNF, 38/149 (25.5\%) included in the dose tapering protocol, $84.4 \%$ men and the mean age $47.2 \pm 10.6$ years. The antecedents $25 \%$ uveitis, $6.3 \%$ psoriasis and $6.3 \%$ inflammatory bowel disease. Regarding the type of optimisation strategy, 32 patients $(84.37 \%)$ followed the protocol for increasing the interval between doses, compared to the rest (15.62\%) who used reduced doses. We found $27 / 38$ patients $(71.05 \%$, Cl: $55.2-$ $83)$ maintained clinical remission with tapering, $9(33.3 \%)$ infliximab, $7(25.9 \%)$ golimumab, $6(22.2 \%)$ etanercept and $5(18.5 \%)$ adalimumab, at a time of drug follow-up of $57.9 \pm 29.7$ months. The demographic factors analysed sex, age, time of evolution and clinical remission, were not found as possible predictors of greater survival in the dose tapering.

\begin{tabular}{|c|c|c|c|c|c|c|}
\hline & \multicolumn{3}{|c|}{ PATIENTS RELAPSE $(n=11)$} & \multicolumn{3}{|c|}{$\begin{array}{l}\text { PATIENTS REMISSION } \\
(\mathrm{n}=27)\end{array}$} \\
\hline & Basal & $\begin{array}{c}\text { Start } \\
\text { tapering }\end{array}$ & Relapse & Basal & $\begin{array}{c}\text { Start } \\
\text { tapering }\end{array}$ & $\begin{array}{l}\text { Last } \\
\text { visit }\end{array}$ \\
\hline $\begin{array}{l}\text { BASDAI (0- } \\
\text { 10) }\end{array}$ & $3.8 \pm 2.4$ & $2 \pm 1.8$ & $3.18 \pm 2.27$ & $4.4 \pm 2.8$ & $2.1 \pm 2.5$ & $1.5 \pm 1.6$ \\
\hline \multicolumn{6}{|l|}{$(0-10)$} & $2.0 \pm 2.4$ \\
\hline $\begin{array}{l}\text { ESR } \\
\left(\mathrm{mm} / 1^{a} \mathrm{~h}\right)\end{array}$ & $\begin{array}{c}17.1 \\
\pm 22.5\end{array}$ & $9.3 \pm 11.1$ & $\begin{array}{c}11.84 \\
\pm 11.29\end{array}$ & $\begin{array}{c}20.4 \\
\pm 18.8\end{array}$ & $7.8 \pm 6.1$ & $8.4 \pm 7.6$ \\
\hline \multirow[t]{2}{*}{$(\mathrm{mg} / \mathrm{L})$} & $\begin{array}{r}10.9 \\
\pm 12.2 \\
\end{array}$ & $9.7 \pm 12.4$ & $3.84 \pm 4.54$ & $\begin{array}{c}14.6 \\
\pm 22.5 \\
\end{array}$ & $3.7 \pm 6.1$ & $2.69 \pm 3.0$ \\
\hline & & & \multicolumn{4}{|c|}{$\mathrm{n}=\mathbf{3 8}$} \\
\hline \multicolumn{3}{|c|}{ Age(years, meantSD) } & \multicolumn{4}{|c|}{$47.2 \pm 10.6$} \\
\hline \multicolumn{3}{|c|}{ Sex(\%) Man/woman } & \multirow{2}{*}{\multicolumn{4}{|c|}{$\begin{array}{l}84.4 / 15.6 \\
12.2 \pm 10.4\end{array}$}} \\
\hline \multicolumn{3}{|c|}{ Time of exolution disease(veaus, mean $\mathrm{SD}$ ) } & & & & \\
\hline \multirow{2}{*}{\multicolumn{3}{|c|}{ Stant biological theranv(manths mean \pm SD) }} & \multicolumn{3}{|c|}{$22.84 \pm 12.68$} & \\
\hline \multirow{2}{*}{\multicolumn{3}{|c|}{ BASDAL $(0-10)$}} & Start antit & & Start tapering & \\
\hline & & & $4.2 \pm 2$ & & $2.07 \pm 1.96$ & \\
\hline \multicolumn{3}{|l|}{ BASFI $(0-10)$} & \multicolumn{2}{|c|}{$4 \pm 2.7$} & $2.8 \pm 2.9$ & \\
\hline \multicolumn{3}{|l|}{ CPR(mg/L) } & \multirow{2}{*}{\multicolumn{2}{|c|}{$\begin{array}{c}13.1 \pm 18.7 \\
19 \pm 20.1\end{array}$}} & $6.4 \pm 9.7$ & \\
\hline $\operatorname{ESR}\left(\mathrm{mm} / 1^{1 / h}\right)$ & & & & & $8.5 \pm 8.5$ & \\
\hline
\end{tabular}

Conclusions: The monitoring of dose tapering of biological therapy in patients with $\mathrm{SpA}$ is possible and allows more than $70 \%$ of patients to maintain the clinica remission of the disease. However, a greater number of patients and longer follow-up are necessary for a solid conclusion. Additionally, our results do not show possible predictors of a longer survival in tapering protocol.

\section{REFERENCE:}

[1] Navarro-Compán V. AntiTNF discontinuation and tapering strategies in patients with axial spondyloarthritis: a systematic literature review. Rheumatology (Oxford) 2016 Jul;55(7):1188-94.

Disclosure of Interest: None declared

DOI: 10.1136/annrheumdis-2018-eular.2964 


\section{SAT0263 PREDICTORS OF REMISSION MAINTENANCE AND SUCCESSFUL THERAPY DISCONTINUATION IN PATIENTS WITH NON-RADIOGRAPHIC AXIAL SPONDYLOARTHRITIS (NR-AXSPA) WHO ACHIEVED SUSTAINED REMISSION ON OPEN-LABEL ADALIMUMAB (ADA) TREATMENT}

J. Sieper $^{1}$, R. Landewé ${ }^{2}$, M. Magrey ${ }^{3}$, J. Anderson ${ }^{4}$, S. Zhong ${ }^{4}$, X. Wang ${ }^{4}$, A. Lertratanakul ${ }^{4}{ }^{1}$ Charité Universitätsmedizin Berlin, Berlin, Germany; ${ }^{2}$ University of Amsterdam, Amsterdam, Netherlands; ${ }^{3}$ Case Western Reserve University School of Medicine at MetroHealth Medical Center, Cleaveland; ${ }^{4}$ AbbVie Inc. North Chicago, USA

Background: Sustained remission is an important treatment goal in patients (pts) with non-radiographic axial SpA (nr-axSpA). Factors predicting successful remission maintenance are unknown.

Objectives: We sought to identify predictors of remission maintenance in $\mathrm{nr}-$ axSpA pts who achieved remission after open-label (OL) adalimumab (ADA) treatment in the ABILITY-3 trial (NCT01808118) and were subsequently randomised to continuation or withdrawal of ADA therapy.

Methods: ABILITY-3 enrolled adult pts with nr-axSpA with objective evidence of active MRI inflammation in the SI joints or spine or elevated high-sensitivity CRP at screening, active disease at baseline (ASDAS $\geq 2.1, B A S D A l \geq 4$, and Patient's Assessment of Total Back Pain score $\geq 4$ ), and inadequate response to $>2$ NSAIDs (table 1). Pts received ADA $40 \mathrm{mg}$ every other wk during a 28-wk OL lead-in period. Pts who achieved sustained remission, defined as ASDAS inactive disease [ID] score $<1.3$ at wks $16,20,24$, and 28 , were randomised to doubleblind withdrawal (placebo; PBO) or continued ADA for 40 wks during period 2 (study wk 68). Stepwise logistic regression was used to identify predictors of sustained remission in those in the continued ADA and withdrawal (PBO) groups. Remission maintenance in period 2 was assessed with the following: ASAS partial remission (PR; score $\leq 2.0$ ) and ASDAS ID at wk 68, ASAS PR and ASDAS ID at every visit, and ASDAS ID for $\geq 5$ of 10 visits.

Abstract SAT0263 - Table 1. Characteristics at Baseline and Wk 28

\begin{tabular}{|c|c|c|c|c|c|c|c|}
\hline \multicolumn{8}{|c|}{ Table. Characteristics at Baseline a } \\
\hline $\begin{array}{l}\text { Variable } \\
\text { Baseline, mean (SD) }\end{array}$ & $\begin{array}{c}\text { ADA } \\
(40 \mathrm{mg} \\
\text { EOW) } \\
\mathrm{n}=152\end{array}$ & $\begin{array}{c}\text { PBO } \\
\mathrm{n}=153\end{array}$ & $P$ Value & Wk 28, mean (SD) & $\begin{array}{c}\mathrm{ADA} \\
\left(\begin{array}{c}\mathrm{ADO} \\
\mathrm{mg} \\
\mathrm{EOW} \\
\mathrm{n}=152\end{array}\right. \\
\mathrm{n}=15\end{array}$ & $\begin{array}{c}\text { PBO } \\
n=153\end{array}$ & $P$ Value \\
\hline Age, y & $\frac{1-1.2}{34.7(10.3)}$ & $35.3(10.2)$ & 0.611 & ASDAS & $0.7(0.4)$ & $0.6(0.4)$ & 0.355 \\
\hline $\begin{array}{l}\text { Female, n (\%) } \\
\text { SpA symptom }\end{array}$ & $\begin{array}{l}56(37) \\
6.4(6.9)\end{array}$ & $\begin{array}{l}60(39) \\
7.1(6.8)\end{array}$ & $\begin{array}{l}0.724 \\
0.358\end{array}$ & $\begin{array}{l}\text { BASDAI } \\
\text { BASFI }\end{array}$ & $\begin{array}{l}0.8(0.8) \\
0.7(1.0)\end{array}$ & $\begin{array}{l}0.7(0.7) \\
0.7(1.2)\end{array}$ & 0.145 \\
\hline duration, y & & & & & & & \\
\hline $\begin{array}{l}\text { HLA-B27 positive, } \mathrm{n} \\
(\%)\end{array}$ & $132(87)$ & $134(88)$ & 0.866 & Hs-CRP, mg/L & $1.5(2.4)$ & $1.4(1.8)$ & 0.647 \\
\hline $\begin{array}{l}\text { ASDAS } \\
\text { BASDAI }\end{array}$ & $\frac{3.5(0.9)}{6.8(14)}$ & $\frac{3.5(0.8)}{6.8(15)}$ & 0.851 & $\begin{array}{l}\text { Pt total back pain } \\
\text { PGA }\end{array}$ & $\frac{1.1(1.4)}{0.8(10)}$ & $\frac{1.0(1.4)}{0.9(1)}$ & 0.567 \\
\hline BASFI & $5.1(2.3)$ & $5.0(2.3)$ & 0.776 & $\begin{array}{l}\text { SPARCC SI joint } \\
\text { scoret }\end{array}$ & $2.6(6.1)$ & $2.5(4.0)$ & 0.775 \\
\hline Hs-CRP, mg/L & $9.9(14.1)$ & $9.1(13.3)$ & 0.576 & $\begin{array}{l}\text { SPARCC spine } \\
\text { score: }\end{array}$ & $1.2(3.8)$ & $1.2(3.8)$ & 0.889 \\
\hline Prt total back pain & $7.0(1.7)$ & $7.0(1.8)$ & 0.946 & & & & \\
\hline & $6.6(1.5)$ & $6.4(1.4)$ & 0.150 & & & & \\
\hline $\begin{array}{l}\text { SPARCC SI joint } \\
\text { score }\end{array}$ & $8.5(12.8)$ & $10.3(13.4)$ & 0.226 & & & & \\
\hline $\begin{array}{l}\text { SPARCC spine score } \\
\text { SPA }\end{array}$ & $3.3(7.5)$ & $3.6(7.2)$ & 0.671 & & & & \\
\hline 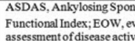 & & & Bathent & $\begin{array}{l}\text { Spondylitis Disease Ac } \\
\text { hs-CRP, high-sensitiv }\end{array}$ & 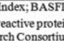 & $\begin{array}{l}\text { Bath Ankylos } \\
\text { POA, physic }\end{array}$ & $\begin{array}{l}\text { Spondylitis } \\
\text { iglobal }\end{array}$ \\
\hline & & & & & & & \\
\hline
\end{tabular}

Results: By wk 68, 100/145 (69\%) ADA pts had not flared, 41\% achieved ASAS PR and $56 \%$ ASDAS ID at wk $68 ; 23 \%$ achieved ASAS PR and $29 \%$ ASDAS ID at every visit, while $70 \%$ achieved ASDAS ID for $\geq 5$ of 10 visits. By wk $68,70 / 148$ (47\%) PBO pts had not flared, $28 \%$ achieved ASAS PR and $33 \%$ ASDAS ID at wk $68 ; 14 \%$ achieved ASAS PR and $15 \%$ ASDAS ID at every visit, while $52 \%$ achieved ASDAS ID for $\geq 5$ of 10 visits. Shorter symptom duration, lower wk 28 BASDAl, and male sex were associated with absence of flare in the continued ADA group. Lower wk 28 ASDAS was associated with absence of flare with ADA withdrawal. Lower wk 28 ASDAS consistently predicted ASAS PR and ASDAS ID at wk 68 , ASAS PR and ASDAS ID at every visit, and ASDAS ID for $\geq 5$ of 10 visits in pts who continued or withdrew ADA.

Conclusions: In nr-axSpA pts who achieved remission after 28-wk OL ADA therapy, lower wk 28 ASDAS is a consistent predictor of remission maintenance using all definitions in both the adalimumab continuation and withdrawal groups, except absence of flare in the adalimumab continuation group, suggesting early aggressive treatment may be beneficial in achieving sustained remission.

Acknowledgements: AbbVie funded the study, contributed to its design and participated in data collection, analysis and interpretation of the data, and in writing, review, and approval of the publication. Medical writing support was provided by Maria Hovenden, PhD, and Janet E. Matsuura, PhD, of Complete Publication Solutions, LLC (North Wales, PA) and was funded by AbbVie.

Disclosure of Interest: J. Sieper Consultant for: AbbVie, Janssen, Lilly, Merck, Novartis, Pfizer, Sun Pharma, and UCB, Speakers bureau: AbbVie, Janssen, Lilly, Merck, Novartis, and Pfizer., R. Landewé Grant/research support from: Abbott, Amgen, Centocor, Novartis, Pfizer, Roche, Schering-Plough, UCB, and Wyeth, Consultant for: consulting or advisory board fees from Abbott/AbbVie, Ablynx, Amgen, Astra-Zeneca, Bristol Myers Squibb, Celgene, Janssen (formerly Centocor), Galapagos, GlaxoSmithKline, Novartis, Novo-Nordisk, Merck, Pfizer Roche, Schering-Plough, TiGenix, UCB, and Wyeth, Employee of: he is director of Rheumatology Consultancy BV, a registered Dutch company., Speakers bureau: Abbott/AbbVie, Amgen, Bristol Myers Squibb, Janssen (formerly Centocor), Merck, Pfizer, Roche, Schering-Plough, UCB, Wyeth, M. Magrey Grant/ research support from: Amgen, AbbVie, and UCB Pharma, Consultant for: UCB and Janssen, J. Anderson Shareholder of: AbbVie, Employee of: AbbVie, S. Zhong Shareholder of: AbbVie, Employee of: AbbVie, X. Wang Shareholder of: AbbVie, Employee of: AbbVie, A. Lertratanakul Shareholder of: AbbVie, Employee of: AbbVie

DOI: 10.1136/annrheumdis-2018-eular.2632

\section{SAT0264 DOES BIOLOGICAL DISEASE-MODIFYING ANTI- RHEUMATIC DRUG NAÏVE VERSUS NON-NAÏVE PATIENTS WITH INFLAMMATORY JOINT DISEASES HAVE SIMILAR GOLIMUMAB DRUG SURVIVAL AND EFFICACY? DATA FROM THE PROSPECTIVE OBSERVATIONAL NOR-DMARD STUDY}

B. Michelsen ${ }^{1,2}$, J. Sexton ${ }^{1}$, T.K. Kvien' ${ }^{1}{ }^{1}$ Dept. of Rheumatology, Diakonhjemmet Hospital, Vinderen, Oslo; ${ }^{2}$ Hospital of Southern Norway Trust, Kristiansand, Norway

Background: Knowledge is limited regarding the impact of previously used biological disease modifying anti-rheumatic drugs (bDMARD) on golimumab drug survival and efficacy in inflammatory joint diseases (IJD).

Objectives: To explore golimumab drug survival and efficacy in bDMARD naïve vs. non-naïve IJD patients, as well as predictors of golimumab discontinuation. Methods: From the observational prospective multicenter Norwegian-DMARD (NOR-DMARD) study rheumatoid arthritis (RA), psoriatic arthritis (PsA) and axial spondyloarthritis (ax-SpA) patients starting golimumab were included. Drug survival was explored by Kaplan-Meier analyses with comparison of bDMARD naïve vs. non-naïve patients with log rank test, stratified by diagnosis. 3 month responses were compared with independent $t$-test, and with ANCOVA adjusted for age, gender, disease duration and baseline values of the respective composite scores. Univariable and multivariable Cox regression analyses including age gender, disease duration, smoking, concomitant synthetic DMARDs (sDMARDs) and previous bDMARD use were performed to identify predictors of golimumab discontinuation.

Results: Mean (SD) age of the $163 \mathrm{RA}, 267$ PsA and 382 ax-SpA patients was $51.2(14.1) / 48.1(11.7) / 41.8(11.1)$ years, disease duration $11.3(10.0) / 8.7(9.0) /$ 10.6 (11.2) years,\%females $76.1 / 55.1 / 44.1 \%$, respectively. Golimumab drug

\begin{tabular}{|c|c|c|c|c|c|c|c|}
\hline \multirow[t]{4}{*}{ Diagnosis } & \multirow{4}{*}{$\begin{array}{l}\text { Composite } \\
\text { score }\end{array}$} & \multicolumn{5}{|c|}{ Changes (baseline minus 3 months) } & \multirow{4}{*}{ p-value } \\
\hline & & \multirow{3}{*}{$\begin{array}{l}\text { Unadjusted analyses } \\
\text { Mean (SD) } \\
\text { bDMARD naïve } \\
\text { patients }\end{array}$} & & \multirow[t]{3}{*}{ p-value } & \multirow{2}{*}{\multicolumn{2}{|c|}{$\begin{array}{l}\text { Adjusted analyses } \\
\text { Estimated marginal means }(95 \% \mathrm{Cl})\end{array}$}} & \\
\hline & & & & & & & \\
\hline & & & $\begin{array}{c}\text { Previous bDMARD } \\
\text { users }\end{array}$ & & $\begin{array}{l}\text { bDMARD naïve } \\
\text { patients }\end{array}$ & $\begin{array}{c}\text { Previous bDMARD } \\
\text { users }\end{array}$ & \\
\hline \multirow[t]{2}{*}{ RA } & $\Delta$ DAS28 & $-1.1(1.3)$ & $-0.7(3.42)$ & 0.39 & $-1.7(-2.6,-0.7)$ & $-0.6(-1.5,0.2)$ & 0.08 \\
\hline & $\Delta \mathrm{CDAl}$ & $-9.0(10.8)$ & $-9.0(13.2)$ & 0.99 & $-11.7(-14.5,-8.9)$ & $-8.7(-11.2,-6.1)$ & 0.10 \\
\hline \multirow[t]{3}{*}{ PsA } & $\Delta$ DAS28 & $-1.2(1.1)$ & $-0.5(1.0)$ & $<0.001$ & $-1.0(-1.3,-0.8)$ & $-0.6(-0.8,-0.3)$ & 0.01 \\
\hline & $\Delta$ CDAl & $-7.1(7.8)$ & $3.8(7.5)$ & 0.005 & $-6.2(-7.6,-4.8)$ & $-4.8(-6.3,-3.3)$ & 0.18 \\
\hline & $\triangle$ BASDAI & $-1.4(2.1)$ & $-0.6(2.1)$ & 0.08 & $-1.2(-1.6,-0.8)$ & $-0.9(-1.4,-0.5)$ & 0.38 \\
\hline \multirow[t]{2}{*}{ Ax-SpA } & $\triangle$ BASDAI & $-1.9(2.4)$ & $-0.9(2.1)$ & $<0.001$ & $-1.9(-2.3,-1.6)$ & $-0.8(-1.2,-0.4)$ & $<0.001$ \\
\hline & $\triangle$ ASDAS & $-1.2(1.3)$ & $-0.5(1.1)$ & $<0.001$ & $-1.1(-1.3,-0.9)$ & $-0.5(-0.8,-0.3)$ & $<0.001$ \\
\hline
\end{tabular}

Identified predictors for golimumab discontinuation were [Hazard Ratio (95\% Cl)]: RA, None; PsA, female gender (1.63 (1.18-2.25), p=0.003) and no concomitant sDMARDs (1.39 (1.01-1.90),

$\mathrm{p}=0.04)$; ax-SpA, female gender [1.97 $(1.50-2.60), \mathrm{p}<0.001]$. 